\title{
Türkiye'de Mahalli İdareler Seçimleri Oy Oranlarının Tahmin Edilmesine Yönelik Bir Model Önerisi
}

\section{A Model Proposal for the Prediction of Local Authorities Elections Vote Rates in Turkey}

\author{
Dr. Öğr. Üyesi Ali Yıldırım - Dr. Öğr. Üyesi Kürşad Emrah Yıldırım² \\ Arş. Gör. Sami Özcan ${ }^{3}$
}

Başvuru Tarihi: 17.10.2018

Kabul Tarihi: 10.04.2019

Öz

Türkiye'de hükümeti temsil edenler ile mahalli idareleri temsil edenlerin ayn siyasi partilerden olması, hizmetin merkezden yerele doğru daha rahat ulaşacağı kanısını taşımaktadır. Bu nedenle milletvekilliği genel seçimlerinin mahalli idareler seçimlerini etkilediği düşünülmektedir. Çalışmada, 1980 sonrasında yapılan milletvekilliği genel seçimlerinin yapıldı̆̆ı dönemde partilerin aldıkları oy oranlarının bir sonraki mahalli idareler seçimlerinde ayn partilerin aldıkları oy oranları üzerindeki etkisi incelenmiştir. Bu amaç doğrultusunda milletvekilliği genel seçimlerinde alınan oy oranları bağımsız, mahalli idareler seçimlerinde alınan oy oranları bağımlı değişkenler olmak üzere regresyon analizi uygulanmıştır. Sonuç olarak milletvekilliği genel seçimlerinde alınan oy oranlarının \%70'in üzerinde mahalli idareler seçimlerinde alınan oy oranlarını etkilediği sonucuna ulaşılmıştır.

Anahtar Kelimeler: Mahalli İdareler Seçimleri, Milletvekilliği Genel Seçimleri, Yerel Seçimler, Regresyon Modeli

\section{Abstract}

There exists a common belief in Turkey on more efficient transition of public services from headquarters to local authorities when the representatives of both government and local authorities are the members of the same political party. Therefore, there is an ongoing debate on the impact of general parliamentary election results on local authorities election results. This study explores the impact of parliamentary election vote rates of political parties on their following local authorities election vote rates in Turkey after 1980. For this purpose, a regression analysis is

\footnotetext{
Ardahan Üniversitesi İIBF, aliyildirim@ardahan.edu.tr, ORCID: 0000-0002-1400-8121

Anadolu Üniversitesi İIBF, keyildirim@anadolu.edu.tr, ORCID: 0000-0002-7824-4916

${ }^{3}$ Ardahan Üniversitesi İIBF, samiozcan@ardahan.edu.tr, ORCID: 0000-0002-7654-7614
} 
performed by considering parliamentary and local authorities election vote rates as independent and dependent variables, respectively. Results reveal that parliamentary election vote rates have a more than $70 \%$ impact on local authorities election vote rates in Turkey.

Keywords: Local Authorities Elections, Parliamentary Elections, Local Elections, Regression Model

\section{Giriş}

Seçimler, vatandaşların yönetime katılımları ile ülkenin yönetim kadrosunun oluşmasında topyekûn milli iradenin belirlenmesini sağlayan ve özgür bir şekilde iradelerinin ortaya konulmasını amaçlayan bir araçtır. Ülkenin iradesini yansıtan seçim sonuçları, içinde bulunulan ekonomik, sosyal ve siyasal bir takım durumlara göre değişiklik gösterebilmektedir. Bununla birlikte herhangi bir zamanda gerçekleştirilen bir seçim, kendinden bir önceki seçim sonuçlarından etkilenebilmekte veya sonraki bir seçimi etkileyebilmektedir. Dolayısıyla bir döngü olarak değerlendirildiğinde kendinden önceki veya sonraki seçimlerin sonuçlarını ekonomik, sosyal ya da siyasal herhangi bir kırılma söz konusu olmadığında oransal olarak kısmen belirleyebilmektedir. Seçim sonuçlarında yaşanan değişimi belirleyen önemli bir unsur ise seçmen davranışıdır. Seçmen davranışını etkileyen faktörleri inceleyen çalışmalar sonucunda seçmen davranışını etkilediği düşünülen çeşitli modeller geliştirilmiştir.

Ülkemizin yönetsel yapısı incelendiğinde 1982 Anayasası'nda yer aldığı üzere hem merkezden hem de yerinden yönetim olmak üzere iki türlü yönetim anlayışının sergilendiği görülmektedir. $\mathrm{Bu}$ çerçevede ülkemizde bir taraftan coğrafi yerinden yönetim, yerel yönetimler ya da mahalli idareler olarak isimlendirilen ve kanunda karar organları seçmenler tarafindan oluşturulacağı ifade edilen organların seçimleri yapılmakta bir taraftan da merkezi hükümetin oluşumu için parlamentonun oluşmasını ve dolaylı olarak hükümetin belirlenmesini sağlayan milletvekilliği genel seçimleri yapılmaktadır. Bu seçimlerin yanı sıra 2007 yılında yapılan değişiklik ile halkın cumhurbaşkanını doğrudan seçmesine ilişkin düzenleme yapılmış ve 2017 yllında yapılan referandum ile ilk defa 2018 milletvekilliği genel seçimleri ile birlikte uygulanmaya başlayan cumhurbaşkanlığı hükümet sistemi getirilmiştir. Bu sistem ile hem cumhurbaşkanı seçimi hem de milletvekili seçimlerinin aynı anda yapılması sağlanmıştır. Demokrasi temelinde yönetim sergileyen ülkelerde olduğu gibi Türkiye'de de seçimler yapılmadan önce seçim sonuçlarını tahmin etme konusunda farklı kesimlerin çeşitli tahminlerde bulunduğu görülmektedir. Bununla birlikte araştırma şirketleri gerçekleştirdikleri anketlere ilişkin analizlerle seçim sonuçlarının olası tahminleri üzerinde fikir yürütmektedirler.

Milletvekilliği genel seçimleri ile mahalli idareler seçimlerine ilişkin tahminler yapıllıken genellikle milletvekilliği genel seçim sonuçlarının mahalli idareler seçim sonuçlarını etkilediği düşüncesi ön plana çıkmaktadır. Çalışmada seçmen davranışını etkileyen modellerden ve bu genellemeden yola çıkılarak 1980 sonrası milletvekilliği genel seçim sonuçlarının mahalli idareler seçim sonuçları üzerindeki etkisi analiz edilmiş ve milletvekilliği genel seçim 
sonuçlarından sonraki mahalli idareler seçim sonuçlarına yönelik tahminde bulunabilmek için bir model önerisi sunulmuştur. Özellikle 2019 yllında gerçekleştirilecek olan mahalli idareler seçimi öncesi böyle bir çalışmanın, partilere yarar sağlayacağı düşünülmektedir.

\section{Seçim ve Seçmen Davranışı}

Seçim kavramı ile ilgili var olan tanımların farklı bakış açları ile yapıldığı görülmektedir. Genel anlamda seçim, bireylerin kendilerine sunulan seçenekler arasından hür ve özgür iradeleri ile yapacakları tercihler olarak tanımlanmaktadır (Akgün, 2007, s. 5). Siyaset bilimi açısından bakıldığında seçim kavramı, kamuya ait bir görevi yürütmek üzere bir kişi veya kurulun, seçmenler tarafından bu görevi yürütmek üzere adaylar arasından tercih yapmasıdır. Yönetilenler tarafından yönetenlerin belirlenip yetkilendirildiği faaliyettir (Türk, 2006, s. 76). Devlete ait siyasetin halk tarafindan belirlenmesi anlamına gelen demokrasinin (Bilir, 2001, s. 5) gereği olan seçimler, siyasi iktidarın sağlanması ve elde tutulmasını sağlayan ve yöneticilere meşruluk kuvveti veren önemli bir kavramdır (Kapani, 1988, s. 84-85). Seçimlerin, yönetme yeteneğine sahip kişilerin belirlenmesi, seçmenlerin görüşlerini yansıtan bir parlamentonun oluşturulması, seçmenlerin çoğunluğunun iradesini yansıtan bir hükümetin var olması ve bu hükümetin güçlü ve istikrarlı bir şekilde faaliyetlerini yürütebilmesi gibi önemli işlevlere sahiptir (Lakeman ve Lambert, 1962, s. 24).

Seçim sisteminin işleyişinde en önemli aktörlerden olan seçmen, karar verme yetkisini seçim sürecinin bir diğer aktörü olan temsilcilere seçimler aracıllğıyla devreden kişidir. Seçim sürecinde seçmenlerin sergilediği en önemli davranış sandığa gitme ve oy kullanma kararıdır. Oy verme aşamasına gelen bir seçmen siyasal olayları izler, bu olaylar sonucunda bir tavır ortaya koyar ve bu olaylara dahil olmaya karar verir (Lester, 1965, s. 16). Karar verme sürecinde seçmenler çeşitli faktörlerin etkisinde kalmaktadır. Bu faktörler incelenirken yapılan araştırmalar seçmen davranışını etkileyen üç önemli modeli ortaya çıkarmıştır. Seçmen davranışı ile ilgili çalışmaların incelendiği modeller şunlardır (Kalender, 2005, s. 39);

- Sosyolojik Yaklaşım

- Psikolojik Yaklaşım

- Rasyonel Tercih Yaklaşımı

Belirlenen bu modeller arasında kopukluk yoktur ve modeller birbirlerini dışlayıcı değildir. Aksine modellerin birbirini tamamladığı söylenebilir (Özcan, 1998, s. 195).

\section{Sosyolojik Yaklaşım}

Seçmen davranışını sosyolojik açıdan ele alan yaklaşım, davranışların belirlenmesinde seçmenlerin ait oldukları sosyal gruba benzer davranış sergilediklerini ve bu grubun çıkarları doğrultusunda hareket ettiklerini savunur. Seçmen davranışı üzerindeki belirleyicilerin toplumsal bölünmeler olduğu ve bu bölünmeleri inançlar, cinsiyet, sınıf gibi unsurların oluşturduğu söylenebilir (Heywood, 2007, s. 311). Sosyolojik yaklaşıma göre birey önemli değildir. Önemli olan grup veya partidir. Seçmen bireysel tercih yapamaz ve grubun hareket ettiği gibi hareket eder (Özkan, 2004, s. 111). Yaklaşıma göre bir arada yaşayan kişilerin, bir takım karakteristik özelliklere sahip kişilerin, aynı sosyal statüye sahip olan, aynı dini etkinliklerde bulunan kişilerin sergileyecekleri seçmen davranışları benzerlik gösterecektir. Bu 
gruplardan bir diğeri ise aile olarak kabul edilmektedir (Çinko, 2006, s. 109). Sosyolojik yaklaşımda davranış belirlerken seçmenin, düşünmesine gerek kalmadığına kanaat getirdiği ve mensup olduğu gruptan farklı düşünmenin yanlış olacağına inandığı görülmektedir (Barut, 2005, s. 315). Columbia Ekolü olarak da bilinen yaklaşım, seçmen davranışının genetik özellikler gibi nesilden nesile taşındığını, uzun yıllar devam ettiğini ve bağımlılığa sebep olduğunu savunur. Dolayısıyla bu seçmenlerin oy tercihleri rasyonel bir düşünceden çok geleneklere duyulan inancın bir sonucu olmaktadır (Berelson vd., 1954, s. 304). Modelin, uzun vadede seçmen davranışının değişmemesini açıklayabiliyorken kısa vadede aynı seçmen davranışında yaşanan değişimi açıllayamaması eleştirilmesine sebep olmuştur (Ünal, 2016, s. 100).

\section{Psikolojik Yaklaşım}

Sosyolojik yaklaşıma eleştiri olarak ortaya çıkan ve onu tamamlama gayreti içerisinde olan ve Michigan Ekolü olarak da bilinen bu yaklaşım seçmenlerin sosyolojik olduğu kadar psikolojik olarak bir partiye bağlı olduğunu savunmaktadır (Erdoğan, 2004, s. 111). Seçmenler daha ergenliğe ulaşmadan bir siyasi düşünceye ve partiye ilgi duymaya başlar ve bu onun ilerleyen yıllarındaki seçim tercihlerine etki eder. Hatta yaşamlarının belli dönemlerinde bir takım olumsuz nedenler ile bu siyasi görüş ve partiden uzaklaşsa bile sonraki yıllarda tekrar aynı görüş ve partiye geri dönmektedir (Akgün, 2007, s. 26). Seçmenin partiye ve siyasi görüşe olan bağl1lı̆̆ bir takım ikna edici ve makul gerekçeler sayesinde değiştirilebilir (Ladd, 2006, s. 4). Sosyolojik yaklaşımdan farklı olarak bu yaklaşımda seçmenin geleneklere inanç yerine daha akılcı davrandığı ve körü körüne bir bağlllık içerisinde olmadığ görülmektedir. Ancak seçmenin sadece geçici olarak davranışı değişmekte siyasi görüş ve partisine olan bağlılı̆̆ devam etmektedir.

Kişide siyasi görüş veya partiye bir aidiyet duygusu oluşturan bu yaklaşım ahlaki söylemler yerine davranış ile alakalı kuralları ortay çıkarmış ve sosyolojik yorumları kabul etmemiştir (Pomper, 1992, s. 147). Temelinde değerler ve kişisel özellikleri barındıran psikolojik modelde seçmenler, sosyolojik yaklaşımda olduğu gibi sadece çevresinden ve iç etmenlerden etkilenmezler ve dış etmenlerin etkisini dikkate alarak bunları yorumlarlar. Bu yorumlamayı yaparken seçmeni bilinçaltı ve içgüdüleri etkilemektedir. Bu nedenle seçmen aklı ve duyguları arasında kalarak tam anlamı ile rasyonel bir tercih yapamayabilir (Gülmen, 1979, s. 41). Bu model benzer siyasi görüşü sürdüren birden fazla parti olması durumunda geçerliliğini kaybetmektedir. Aynı siyasi görüşü savunan birden fazla parti olması durumunda seçmen davranışının psikolojik yaklaşımdan uzaklaşarak faydacı bir yaklaşıma doğru yönlendiği görülmektedir (Ünal, 2016, s. 103).

\section{Rasyonel Tercih Yaklaşımı}

Temeli, seçmenlerin oy kullanırken kendi çıkarlarına göre hareket etmesi olan bu yaklaşımda seçmen kendisine en fazla hizmeti getireceğini düşündügü siyasi görüş veya partiyi tercih etmektedir. Diğer yaklaşımlardan daha fazla akılcı olan bu yaklaşımda duygusallık arka planda yer almakta ve seçmen çevresinden neredeyse hiç etkilenmediği savunulmaktadır (Özer ve 
Meder, 2008, s. 33). Bu modelde seçmenlerin değerlendirdiği başlıca huşular şöyle sıralanabilir (Altıntaş, 2010, s. 28-29);

- Seçmenler, kendilerine sunulacak hizmetleri hem mevcut hükümet hem de muhalefet açısından değerlendirir ve karşılaştırır. Belirlediği farka göre tutum geliştirir.

- Çok partili seçim sistemlerinde diğer seçmen davranışlarını inceler ve bu davranışları da tutum belirlemede kullanır.

- Seçmenin görüşünü taşıyan partilerden birisinin iktidarda diğerinin muhalefette olması sebebiyle seçmen karar vermede zorlanıyorsa karar verirken önceliğini iktidar partisinden yana kullanır ve iktidar partisinin icraatlarını öncekiler ile karşılaştırarak karar verir.

Rasyonel tercih teorisinde seçmenler için temel nokta ideolojiler değildir. Seçmenin esas kabul ettiği unsur somut göstergelerdir (Downs, 1957, s. 98). Örneğin, bir seçmen desteklediği partinin kazanacağ 1 düşündüğünde oyunu partisinden yana kullanacaktır. Ancak tersi bir durumda istemedikleri ve seçimi kazanacaklarını düşündüğü partinin kazanmamasını sağlayacak bir partiye oy vereceklerdir (Nergiz ve Akyıldız, 2012, s. 182). Rasyonel tercih modelinin temelinde ekonomik model ve stratejik model olmak üzere iki modelin olduğu ve rasyonel tercih modelinin bu iki modelin birleşimi olduğu düşünülmektedir. Verilen örnek seçmenin stratejik oy verme davranışını temsil etmektedir (Ünal, 2016, s. 111).

Özellikle mahalli idareler seçimlerinde seçmenlerin daha faydacı bir davranış sergileyerek, iktidar partisi temsilcilerini seçmeleri rasyonel tercih modelinin seçimlere yansımasına bir örnek teşkil etmektedir. Bu nedenle çalışmanın çıkış noktası olarak kabul edilen ve genel bir kanı olan mahalli idare temsilcileri ile hükümet temsilcilerinin aynı siyasi partiden olmasının kamu hizmetlerinin sunumunu hızlandıracağı düşüncesi seçmen davranışı modellerinden rasyonel tercih modeli ile açıklanabileceği için bu çalışmada milletvekilliği genel seçim sonuçlarının mahalli idareler seçim sonuçlarına etkisi bu model bağlamında incelenmiştir.

\section{Türkiye'de Gerçekleştirilen Seçimlerin İncelenmesi}

Tek partili dönemin sona ermesi ile birlikte ilk kez 1946 yılında çok partili seçim gerçekleştiren Türkiye bu tarihten sonra düzenli olarak seçimler gerçekleştirmiştir. Çalışma kapsamında ele alınan milletvekilliği genel seçimlerine ait genel bilgiler Tablo1'de, mahalli idareler seçimlerine ilişkin genel bilgiler ise Tablo 2'de kısaca sunulmuştur. 
Tablo 1. 1987 ile 2011 Arasında Yapılan Milletvekilliği Genel Seçimlerine ilişkin Genel Bilgiler

\begin{tabular}{|l|c|c|c|c|}
\hline Tarih & $\begin{array}{c}\text { Kayıtı } \\
\text { seçmen sayısı }\end{array}$ & $\begin{array}{c}\text { Oy kullanan } \\
\text { seçmen sayısı }\end{array}$ & $\begin{array}{c}\text { Katılım } \\
\text { oranı } \\
\text { (\%) }\end{array}$ & $\begin{array}{c}\text { Toplam } \\
\text { geçerli oy } \\
\text { sayısı }\end{array}$ \\
\hline 29 Kasım 1987 & 26.376 .926 & 24.603 .541 & 93,3 & 23.971 .629 \\
\hline 20 Ekim 1991 & 29.979 .123 & 25.157 .089 & 83,9 & 24.416 .666 \\
\hline 24 Aralık 1995 & 34.155 .981 & 29.101 .469 & 85,2 & 28.126 .993 \\
\hline 3 Kasım 2002 & 41.407 .027 & 32.768 .161 & 79,1 & 31.528 .783 \\
\hline 22 Temmuz 2007 & 42.799 .303 & 36.056 .293 & 84,2 & 35.049 .691 \\
\hline 12 Haziran 2011 & 52.806 .322 & 43.914 .948 & 83,2 & 42.941 .763 \\
\hline
\end{tabular}

Kaynak: www.tuik.gov.tr

Tablo 1 incelendiğinde en yüksek katılım oranı \%93,3 ile 29 Kasım 1987 milletvekilliği genel seçiminde gerçekleşmiştir. Bu seçimi \%85,2'lik katılım oranı ile 24 Aralık 1995 seçimleri, \%84,2'lik katılım oranı ile 22 Temmuz 2007 seçimleri, \%83,9'luk katılım oranı ile 20 Ekim 1991 seçimleri ve \%83,2'lik katılım oranı ile 12 Haziran 2011 seçimleri takip etmektedir. En az katılım ise \%79,1 oranı ile 3 Kasım 2002 milletvekilliği genel seçimlerine olmuştur. 
Tablo 2. 1989 ile 2014 Arasında Yapılan Mahalli Idareler Seçimlerine ilişkin Genel Bilgiler

\begin{tabular}{|c|c|c|c|c|c|}
\hline Seçim & Tarih & $\begin{array}{l}\text { Kayıtlı seçmen } \\
\text { sayısı }\end{array}$ & $\begin{array}{l}\text { Oy kullanan } \\
\text { seçmen sayısı }\end{array}$ & $\begin{array}{c}\text { Katılım oranı } \\
\text { (\%) }\end{array}$ & Geçerli oy sayısı \\
\hline \multirow{6}{*}{$\begin{array}{l}\text { Belediye } \\
\text { Başkanlığı }\end{array}$} & 26 Mart 1989 & 18.090 .657 & 14.107.146 & 78 & 13.432 .841 \\
\hline & 27 Mart 1994 & 23.366 .089 & 21.142 .499 & 90,5 & 19.897 .335 \\
\hline & 18 Nisan 1999 & 28.889 .819 & 24.601 .491 & 85,2 & 23.372 .675 \\
\hline & 28 Mart 2004 & 34.213 .138 & 25.066 .859 & 73,3 & 24.074 .027 \\
\hline & 29 Mart 2009 & 39.809 .274 & 33.510 .343 & 84,2 & 32.299 .515 \\
\hline & 6 Mayıs 2014 & 48.905 .743 & 43.609 .960 & 89,2 & 41.766 .549 \\
\hline \multirow{6}{*}{$\begin{array}{l}\text { Büyükşehir } \\
\text { Belediye } \\
\text { Başkanlığı }\end{array}$} & 26 Mart 1989 & 7.450 .605 & 5.398 .806 & 72,5 & 5.144 .576 \\
\hline & 27 Mart 1994 & 10.904 .360 & 9.739 .574 & 89,3 & 9.143 .354 \\
\hline & 18 Nisan 1999 & 13.027 .329 & 10.953 .108 & 84,1 & 10.432 .858 \\
\hline & 28 Mart 2004 & 15.426 .031 & 10.891 .703 & 70,6 & 10.468 .870 \\
\hline & 29 Mart 2009 & 22.677 .450 & 18.861 .493 & 83,2 & 18.183 .894 \\
\hline & 6 Mayıs 2014 & 40.727 .194 & 36.440 .968 & 89,5 & 34.913 .716 \\
\hline \multirow{6}{*}{$\begin{array}{l}\text { İ Genel } \\
\text { Meclisi }\end{array}$} & 26 Mart 1989 & 28.077 .317 & 22.877 .723 & 81,5 & 22.147 .749 \\
\hline & 27 Mart 1994 & 31.960 .555 & 29.456 .498 & 92,2 & 28.208 .036 \\
\hline & 18 Nisan 1999 & 37.429 .120 & 32.503 .578 & 86,9 & 31.468 .511 \\
\hline & 28 Mart 2004 & 43.552 .931 & 33.211 .457 & 76,3 & 32.268 .496 \\
\hline & 29 Mart 2009 & 48.049 .446 & 40.932 .260 & 85,2 & 39.988 .763 \\
\hline & 6 Mayıs 2014 & 11.991 .225 & 10.619 .055 & 88,6 & 10.240 .022 \\
\hline \multirow{6}{*}{$\begin{array}{l}\text { Belediye } \\
\text { Meclisi }\end{array}$} & 26 Mart 1989 & 18.090 .657 & 14.107.146 & 78,0 & 13.237 .086 \\
\hline & 27 Mart 1994 & 23.366 .089 & 21.102 .428 & 90,3 & 19.734 .355 \\
\hline & 18 Nisan 1999 & 28.889 .819 & 24.527 .241 & 84,9 & 23.164 .822 \\
\hline & 28 Mart 2004 & 34.213 .138 & 25.067 .950 & 73,3 & 23.893 .656 \\
\hline & 29 Mart 2009 & 39.809 .272 & 33.461 .620 & 84,1 & 32.086 .214 \\
\hline & 6 Mayıs 2014 & 48.905 .721 & 43.593 .617 & 89,1 & 41.575 .471 \\
\hline
\end{tabular}

Kaynak: www.tuik.gov.tr

Katılım oranları incelendiğinde 26 Mart 1989 mahalli idareler seçimlerinden belediye başkanlığı seçimlerine katılım oranı \%78, büyükş̧ehir belediye başkanlığ1 seçimlerine \%72,5, il genel meclis üyeliği seçimlerine $\% 81,5$ ve belediye meclis üyeliği seçimlerine ise $\% 78$ olarak gerçekleşmiştir. 27 Mart 1994 mahalli idareler seçimlerinden belediye başkanlığ seçimlerine katılım oranı \%90,5, büyükşehir belediye başkanlığı seçimlerine $\% 89,3$, il genel meclis üyeliği seçimlerine \%92,2 ve belediye meclis üyeliği seçimlerine ise $\% 90,3$ olarak gerçekleşmiştir. 18 Nisan 1999 mahalli idareler seçimlerinden belediye başkanlığı seçimlerine katılım oranı \%85,2, büyükşehir belediye başkanlığı seçimlerine $\% 84,1$, il genel meclis üyeliği seçimlerine $\% 86,9$ ve belediye meclis üyeliği seçimlerine ise \%84,9 olarak gerçekleşmiştir. 28 Mart 2004 mahalli idareler seçimlerinden belediye başkanlığ seçimlerine katılım oranı $\% 73,3$, büyükşehir belediye başkanlığı seçimlerine \%70,6, il genel meclis üyeliği seçimlerine \%76,3 ve belediye meclis üyeliği seçimlerine ise \%73,3 olarak gerçekleşmiştir. 29 Mart 2009 mahalli idareler seçimlerinden belediye başkanlığı seçimlerine katılım oranı \%84,2, büyükşehir belediye başkanlığı seçimlerine $\% 83,2$, il genel meclis üyeliği seçimlerine $\% 85,2$ ve belediye meclis üyeliği seçimlerine ise \%84,1 olarak gerçekleşmiştir. Son olarak 6 Mayıs 2014 mahalli idareler 
seçimlerinden belediye başkanlığı seçimlerine katılım oranı $\% 89,2$, büyükşehir belediye başkanlığı seçimlerine \%89,5, il genel meclis üyeliği seçimlerine $\% 88,6$ ve belediye meclis üyeliği seçimlerine ise \%89,1 olarak gerçekleşmiştir. Mahalli idareler seçimlerinden olan belediye başkanlığı seçimlerine en yüksek katılım \%90,5 katılım oranı ile 27 Mart 1994 seçimleri olurken en düşük katılım \%73,3 katılım oranı ile 28 Mart 2004 seçimlerinde gerçekleşmiştir. Büyükşehir belediye başkanlığı seçimlerinde ise en yüksek katılım \%89,5 katılım ile 6 Mayıs 2014 seçimleri olmuş ve buna karşın \%72,5 katılım oranı ile 26 Mart 1989 seçimleri en az katılımın olduğu büyükşsehir belediye başkanlığı seçimleri olmuştur. İl genel meclis üyeliği ve belediye meclis üyeliği seçimleri için katılım oranları incelendiğinde belediye başkanlığı seçimlerindeki gibi en yüksek katılım 27 Mart 1994 seçimlerinde, en düşük katılım ise 28 Mart 2004 seçimlerinde gerçekleşmiştir. Buna göre il genel meclis üyeliği seçimlerinde en yüksek katılım \%92,2 ve en düşük katılım \%76,3 olurken belediye meclis üyeliği seçimlerinde en yüksek katılım \%90,3 ve en düşük katılım \%73,3 olarak sonuçlanmıştır.

Tablo 3 ve Tablo 8 arasındaki tablolarda yer alan bilgiler milletvekilliği genel seçimleri ile ilgili mahalli idareler seçimlerinin her ikisine de katılan partileri ve bu partilerin almış oldukları oy oranlarını göstermektedir.

Tablo 3. 1987 Milletvekilliği Genel Seçimleri ile 1989 Yerel Seçimlerine Katılan Partiler ve Türkiye Geneli Aldıkları Oy Oranları

\begin{tabular}{|c|c|c|c|c|c|}
\hline \multirow[b]{2}{*}{ Partiler } & \multirow{2}{*}{$\begin{array}{l}29 \text { Kasım } 1987 \\
\text { Milletvekilliği } \\
\text { Genel Seçimleri } \\
\text { Alınan Oy } \\
\text { Oranları (\%) } \\
\end{array}$} & \multicolumn{4}{|c|}{26 Mart 1989 Yerel Seçimleri Alınan Oy Oranları (\%) } \\
\hline & & $\begin{array}{l}\text { Belediye } \\
\text { Başkanlığı }\end{array}$ & $\begin{array}{l}\text { Büyükşehir } \\
\text { Belediye } \\
\text { Başkanlığı }\end{array}$ & $\begin{array}{l}\text { II Genel } \\
\text { Meclis } \\
\text { Üyeliği }\end{array}$ & $\begin{array}{l}\text { Belediye Meclis } \\
\text { Üyeliği }\end{array}$ \\
\hline $\begin{array}{l}\text { Anavatan } \\
\text { (ANAP) }\end{array}$ & 36,3 & 23,7 & 23,6 & 21,8 & 23,5 \\
\hline $\begin{array}{ll}\text { Demokratik } & \text { Sol } \\
\text { Parti (DSP) } & \end{array}$ & 8,5 & 6,5 & 8,7 & 9,0 & 6,7 \\
\hline $\begin{array}{l}\text { Doğru } \\
\text { (DYP) }\end{array}$ & 19,1 & 23,5 & 17,9 & 25,1 & 23,7 \\
\hline $\begin{array}{l}\text { Islahatçı Demokrasi } \\
\text { Partisi (IDP) }\end{array}$ & 0,8 & 0,5 & 0,4 & 1,0 & 0,5 \\
\hline $\begin{array}{l}\text { Milliyetçi Çalışma } \\
\text { Partisi (MÇP) }\end{array}$ & 2,9 & 3,0 & 1,9 & 4,1 & 3,3 \\
\hline Refah Partisi (RP) & 7,2 & 8,7 & 9,0 & 9,8 & 8,9 \\
\hline $\begin{array}{l}\text { Sosyaldemokrat } \\
\text { Halkçı Parti (SHP) }\end{array}$ & 24,8 & 32,8 & 38,4 & 28,7 & 33,2 \\
\hline Bağımsızlar & 0,4 & 1,3 & 0,1 & 0,5 & 0,2 \\
\hline
\end{tabular}

Kaynak: www.tuik.gov.tr

29 Kasım 1987 milletvekilliği genel ve ardından yapılan 26 Mart 1989 mahalli idareler seçimlerinin her ikisine de ANAP, DSP, DYP, IDP, MÇP, RP ve SHP olmak üzere toplam 7 parti katılmıştır. Milletvekilliği genel seçimlerinde $\% 36,3$ oy oranı ile birinci parti ANAP olurken 26 Mart 1989 mahalli idareler seçimlerinin tümünde SHP birinci parti olarak seçimi tamamlamıştır. 
Tablo 4. 1991 Milletvekilliği Genel Seçimleri ile 1994 Yerel Seçimlerine Katılan Partiler ve Türkiye Geneli Aldıkları Oy Oranları

\begin{tabular}{|c|c|c|c|c|c|}
\hline \multirow[b]{2}{*}{ Partiler } & \multirow{2}{*}{$\begin{array}{lr}20 \text { Ekim } 1991 \\
\text { Milletvekilliği } \\
\text { Genel Seçimleri } \\
\text { Alınan } \quad \text { Oy } \\
\text { Oranları (\%) }\end{array}$} & \multicolumn{4}{|c|}{27 Mart 1994 Yerel Seçimleri Alınan Oy Oranları (\%) } \\
\hline & & Belediye Başkanlığı & $\begin{array}{l}\text { Büyükşehir Belediye } \\
\text { Başkanlığı }\end{array}$ & $\begin{array}{l}\text { II Genel } \\
\text { Meclis } \\
\text { Üyeliği }\end{array}$ & $\begin{array}{l}\text { Belediye Meclis } \\
\text { Üyeliği }\end{array}$ \\
\hline $\begin{array}{l}\text { Anavatan } \\
\text { (ANAP) }\end{array}$ & 24,0 & 22,8 & 21,8 & 21,0 & 22,7 \\
\hline $\begin{array}{l}\text { Demokratik Sol Parti } \\
\text { (DSP) }\end{array}$ & 10,8 & 7,9 & 11,2 & 8,8 & 8,4 \\
\hline $\begin{array}{lll}\text { Doğru } & \text { Yol } & \text { Partisi } \\
\text { (DYP) } & & \end{array}$ & 27,0 & 19,0 & 15,9 & 21,4 & 18,9 \\
\hline Refah Partisi (RP) & 16,9 & 18,9 & 22,4 & 19,1 & 19,1 \\
\hline $\begin{array}{l}\text { Sosyaldemokrat } \\
\text { Halkçı Parti (SHP) }\end{array}$ & 20,8 & 16,8 & 19,7 & 13,6 & 16,8 \\
\hline Bağımsızlar & 0,1 & 0,8 & 0,1 & 0,3 & 0,1 \\
\hline
\end{tabular}

Kaynak: www.tuik.gov.tr

20 Ekim 1991 milletvekilliği genel seçimlerine ve devamında yapılan 27 Mart 1994 mahalli idareler seçimlerine ANAP, DSP, DYP, RP ve SHP olmak üzere katılan toplam 5 parti olmuştur. 20 Ekim 1991 milletvekilliği genel seçimlerinde \%27,0 oy oranı ile en yüksek oy oranına sahip parti DYP olmuştur. 27 Mart 1994 belediye başkanlığı, il genel meclis üyeliği ve belediye meclis üyeliği seçimlerinde ANAP birinci parti olurken büyükşehir belediye başkanlığ seçimlerinde \%22,4 oy oranı ile RP, ANAP’ın önünde yer almıştır.

Tablo 5. 1995 Milletvekilliği Genel Seçimleri ile 1999 Yerel Seçimlerine Katılan Partiler ve Türkiye Geneli Aldıkları Oy Oranları

\begin{tabular}{|c|c|c|c|c|c|}
\hline \multirow[b]{2}{*}{ Partiler } & \multirow{2}{*}{$\begin{array}{l}24 \quad \text { Aralık } 1995 \\
\text { Milletvekilliği } \\
\text { Seçimleri Alınan Oy } \\
\text { Oranları (\%) }\end{array}$} & \multicolumn{4}{|c|}{18 Nisan 1999 Yerel Seçimleri Alınan Oy Oranları (\%) } \\
\hline & & $\begin{array}{l}\text { Belediye } \\
\text { Başkanlığı }\end{array}$ & $\begin{array}{l}\text { Büyükşehir Belediye } \\
\text { Başkanlığı }\end{array}$ & $\begin{array}{l}\text { IIl Genel } \\
\text { Meclis } \\
\text { Üyeliği }\end{array}$ & $\begin{array}{l}\text { Belediye Meclis } \\
\text { Üyeliği }\end{array}$ \\
\hline $\begin{array}{l}\text { Anavatan Partisi } \\
\text { (ANAP) }\end{array}$ & 19,6 & 17,4 & 16,9 & 15,1 & 17,1 \\
\hline $\begin{array}{ll}\text { Cumhuriyet } & \text { Halk } \\
\text { Partisi (CHP) } & \end{array}$ & 10,7 & 13,8 & 16,5 & 11,1 & 13,3 \\
\hline $\begin{array}{ll}\text { Demokratik } & \text { Sol } \\
\text { Parti (DSP) } & \end{array}$ & 16,6 & 15,2 & 19,3 & 18,7 & 16,2 \\
\hline $\begin{array}{l}\text { Doğru } \text { Yol } \\
\text { (DYP) }\end{array}$ & 19,2 & 12,8 & 7,4 & 13,2 & 12,5 \\
\hline $\begin{array}{l}\text { Halkın Demokrasi } \\
\text { Partisi (HADEP) }\end{array}$ & 4,2 & 3,4 & 3,8 & 3,5 & 3,5 \\
\hline İşçi Partisi (IP) & 0,2 & 0,1 & 0,1 & 0,2 & 0,1 \\
\hline Millet Partisi & 0,5 & 0,1 & 0,1 & 0,3 & 0,1 \\
\hline $\begin{array}{l}\text { Milliyetçi Hareket } \\
\text { Partisi (MHP) }\end{array}$ & 8,2 & 15,2 & 10,3 & 17,1 & 15,7 \\
\hline $\begin{array}{l}\text { Yeniden Doğuş } \\
\text { Partisi (YDP) }\end{array}$ & 0,3 & 0,1 & 0,1 & 0,1 & 0,1 \\
\hline Bağımsızlar & 0,5 & 0,6 & 0,1 & 0,2 & 0,1 \\
\hline
\end{tabular}

Kaynak: www.tuik.gov.tr 
24 Aralık 1995 milletvekilliği genel ve 18 Nisan 1999 mahalli idareler seçimlerinin ikisine de katılan toplam 9 parti olmuştur. Milletvekilliği genel seçimlerinde ANAP \%19,6 oy oranı ile seçimi birinci sırada tamamlamıştır. 18 Nisan 1999 belediye başkanlığı seçimlerinde \%17,4 oy oranıyla ve belediye meclis üyeliği seçimlerinde $\% 17,1$ oy oranı ANAP birinci parti olurken büyükşehir belediye başkanlığı seçiminde $\% 19,3$ oy oranı ve il genel meclis üyeliğinde de $\% 18,7$ oy oranı ile DSP seçimi önde bitirmiştir.

Tablo 6. 2002 Milletvekilliği Genel Seçimleri ile 2004 Yerel Seçimlerine Katılan Partiler ve Türkiye Geneli Aldıkları Oy Oranları

\begin{tabular}{|c|c|c|c|c|c|}
\hline \multirow[b]{2}{*}{ Partiler } & \multirow{2}{*}{$\begin{array}{l}3 \text { Kasım } 2002 \\
\text { Milletvekilliği } \\
\text { Genel Seçimleri } \\
\text { Alınan Oy } \\
\text { Oranları (\%) }\end{array}$} & \multicolumn{4}{|c|}{28 Mart 2004 Yerel Seçimleri Alınan Oy Oranları (\%) } \\
\hline & & Belediye Başkanlığı & $\begin{array}{l}\text { Büyükşehir Belediye } \\
\text { Başkanlığı }\end{array}$ & $\begin{array}{l}\text { Il Genel Meclis } \\
\text { Üyeliği }\end{array}$ & $\begin{array}{l}\text { Belediye } \\
\text { Üyeliği }\end{array}$ \\
\hline $\begin{array}{lr}\text { Adalet } & \text { ve } \\
\text { Kalkınma } & \text { Partisi } \\
(\mathrm{AKP}) & \\
\end{array}$ & 34,3 & 40,2 & 46,1 & 41,7 & 40,3 \\
\hline $\begin{array}{l}\text { Anavatan Partisi } \\
\text { (ANAP) }\end{array}$ & 5,1 & 3,0 & 0,8 & 2,5 & 2,9 \\
\hline $\begin{array}{l}\text { Büyük Birlik } \\
\text { Partisi (BBP) }\end{array}$ & 1,0 & 0,6 & 0,4 & 1,2 & 0,7 \\
\hline $\begin{array}{l}\text { Bağımsız Türkiye } \\
\text { Partisi (BTP) }\end{array}$ & 0,5 & 0,3 & 0,3 & 0,5 & 0,3 \\
\hline $\begin{array}{l}\text { Cumhuriyet Halk } \\
\text { Partisi (CHP) }\end{array}$ & 19,4 & 20,7 & 24,5 & 18,2 & 20,6 \\
\hline $\begin{array}{l}\text { Demokratik Sol } \\
\text { Parti (DSP) }\end{array}$ & 1,2 & 1,9 & 2,3 & 2,1 & 2,0 \\
\hline $\begin{array}{l}\text { Doğru Yol Partisi } \\
\text { (DYP) }\end{array}$ & 9,5 & 9,4 & 5,4 & 10,0 & 9,6 \\
\hline Genç Parti (GP) & 7,2 & 2,4 & 3,0 & 2,6 & 2,5 \\
\hline İşçi Partisi (IP) & 0,5 & 0,1 & 0,2 & 0,2 & 0,1 \\
\hline $\begin{array}{l}\text { Liberal Demokrat } \\
\text { Parti (LDP) }\end{array}$ & 0,3 & $0,001641^{5}$ & $0^{6}$ & $0^{3}$ & $0,001636^{2}$ \\
\hline Millet Partisi & 0,2 & $0,049809^{2}$ & $0,026995^{2}$ & $0,026995^{2}$ & $0,051156^{2}$ \\
\hline $\begin{array}{l}\text { Milliyetçi } \\
\text { Hareket Partisi } \\
\text { (MHP) }\end{array}$ & 8,4 & 10,1 & 5,1 & 10,5 & 10,5 \\
\hline $\begin{array}{l}\text { Özgürlük } \\
\text { Dayanışma } \\
\text { Partisi (ÖDP) }\end{array}$ & 0,3 & 0,1 & $0^{3}$ & $0,038362^{2}$ & 0,1 \\
\hline $\begin{array}{ll}\text { Saadet } & \text { Partisi } \\
\text { (SP) } & \\
\end{array}$ & 2,5 & 4,8 & 4,0 & 4,0 & 4,6 \\
\hline $\begin{array}{l}\text { Türkiye } \\
\text { Komünist Parti } \\
\text { (TKP) }\end{array}$ & 0,2 & 0,1 & 0,2 & 0,3 & 0,1 \\
\hline $\begin{array}{l}\text { Yeni Türkiye } \\
\text { Parti (YTP) }\end{array}$ & 1,2 & 0,2 & 0,1 & 0,2 & 0,2 \\
\hline Bağımsızlar & 1,0 & 1,0 & 0,2 & 0,7 & 0,2 \\
\hline
\end{tabular}


3 Kasım 2002 milletvekilliği genel ve 28 Mart 2004 mahalli idareler seçimlerinin ikisine de katılan toplam 16 parti olmuştur. Milletvekilliği genel seçimlerinde AKP \%34,3 oy oranıyla, 28 Mart 2004 belediye başkanlığı seçimlerinde $\% 40,2$ oy oranıyla, büyükşehir belediye başkanlığı seçimlerinde $\% 46,1$ oy oranıyla, il genel meclis üyeliği seçimlerinde $\% 41,7$ oy oranıyla ve belediye meclis üyeliği seçimlerinde $\% 40,3$ oy oranıyla birinci parti olmuştur.

Tablo 7. 2007 Milletvekilliği Genel Seçimleri ile 2009 Yerel Seçimlerine Katılan Partiler ve Türkiye Geneli Aldıkları Oy Oranları

\begin{tabular}{|c|c|c|c|c|c|}
\hline \multirow[b]{2}{*}{ Partiler } & \multirow[b]{2}{*}{$\begin{array}{l}22 \text { Temmuz } \\
2007 \\
\text { Milletvekilliği } \\
\text { Genel } \\
\text { Seçimleri } \\
\text { Alınan Oy } \\
\text { Oranları (\%) }\end{array}$} & \multicolumn{4}{|c|}{29 Mart 2009 Yerel Seçimleri Alınan Oy Oranları (\%) } \\
\hline & & $\begin{array}{l}\text { Belediye } \\
\text { Başkanlığı }\end{array}$ & $\begin{array}{l}\text { Büyükşehir } \\
\text { Belediye } \\
\text { Başkanlığı }\end{array}$ & $\begin{array}{l}\text { Il Genel Meclis } \\
\text { Üyeliği }\end{array}$ & $\begin{array}{l}\text { Belediye Meclis } \\
\text { Üyeliği }\end{array}$ \\
\hline $\begin{array}{l}\text { Adalet ve } \\
\text { Kalkınma } \\
\text { Partisi (AKP) }\end{array}$ & 46,6 & 38,6 & 42,2 & 38,4 & 38,2 \\
\hline $\begin{array}{l}\text { Bağımsız } \\
\text { Türkiye Partisi } \\
\text { (BTP) }\end{array}$ & 0,5 & 0,3 & 0,3 & 0,4 & 0,3 \\
\hline $\begin{array}{l}\text { Cumhuriyet } \\
\text { Halk Partisi } \\
\text { (CHP) }\end{array}$ & 20,9 & 24,7 & 32,4 & 23,1 & 24,8 \\
\hline $\begin{array}{l}\text { Demokrat } \\
\text { Parti (DP) }\end{array}$ & 5,4 & 3,6 & 1,0 & 3,8 & 3,7 \\
\hline $\begin{array}{ll}\text { Emek } & \text { Partisi } \\
\text { (EMEP) } & \\
\end{array}$ & 0,1 & $0,047363^{7}$ & $0,004405^{4}$ & 0,1 & 0,1 \\
\hline $\begin{array}{l}\text { Halkın } \\
\text { Yükselişi } \\
\text { Partisi (HYP) }\end{array}$ & 0,5 & $0,025363^{4}$ & $0,039463^{4}$ & $0,015497^{4}$ & $0,017347^{4}$ \\
\hline İşçi Partisi (IP) & 0,4 & $0,002684^{4}$ & $0,002167^{4}$ & 0,3 & $0,007037^{4}$ \\
\hline $\begin{array}{l}\text { Liberal } \\
\text { Demokrat } \\
\text { Parti (LDP) }\end{array}$ & 0,1 & $0,026651^{4}$ & $0,046844^{4}$ & $0,005714^{4}$ & $0,007639^{4}$ \\
\hline $\begin{array}{l}\text { Milliyetçi } \\
\text { Hareket Partisi } \\
\text { (MHP) }\end{array}$ & 14,3 & 16,5 & 12,4 & 16,0 & 16,6 \\
\hline $\begin{array}{l}\text { Özgürlük ve } \\
\text { Dayanışma } \\
\text { Partisi (ÖDP) }\end{array}$ & 0,2 & 0,1 & $0,005714^{4}$ & 0,2 & 0,1 \\
\hline $\begin{array}{l}\text { Saadet Partisi } \\
\text { (SP) }\end{array}$ & 2,3 & 5,4 & 3,8 & 5,2 & 5,6 \\
\hline $\begin{array}{l}\text { Türkiye } \\
\text { Komünist Parti } \\
\text { (TKP) }\end{array}$ & 0,2 & 0,1 & 0,1 & 0,2 & $0,000106^{4}$ \\
\hline Bağımsızlar & 5,2 & 0,7 & 0,3 & 0,4 & 0,1 \\
\hline
\end{tabular}

Kaynak: www.tuik.gov.tr

7 İlgili seçimde \%0,1'in altında oy oranına sahip olmuştur. Almış olduğu oy sayısı çok az olduğu için TÜİK verilerinde oy oranı 0 olarak gösterilmiştir. Analizlerin daha sağlıklı olması için Geçerli Oy Sayısı / Alınan Oy Sayısı işlemi ile tekrar hesaplanmıştır. 
22 Temmuz 2007 milletvekilliği genel seçimlerinde AKP \%46,6 oy oranı ile birinci parti olmuştur. Milletvekilliği genel seçimlerinde olduğu gibi 29 Mart 2009 belediye başkanlığ seçimlerinde $\% 38,6$ oy oranıyla, büyükşehir belediye başkanlığı seçimlerinde $\% 42,2$ oy oranıyla, il genel meclis üyeliği seçimlerinde $\% 38,4$ oy oranıyla ve belediye meclis üyeliği seçimlerinde ise \%38,2 oy oranıyla AKP seçimi önde tamamlamıştır.

Tablo 8. 2011 Milletvekilliği Genel Seçimleri ile 2014 Yerel Seçimlerine Katılan Partiler ve Türkiye Geneli Aldıkları Oy Oranları

\begin{tabular}{|c|c|c|c|c|c|}
\hline \multirow[b]{2}{*}{ Partiler } & \multirow{2}{*}{$\begin{array}{l}12 \text { Haziran } 2011 \\
\text { Milletvekilliği } \\
\text { Genel Seçimleri } \\
\text { Alınan Oy } \\
\text { Oranları (\%) }\end{array}$} & \multicolumn{4}{|c|}{6 Mayıs 2014 Yerel Seçimleri Alınan Oy Oranları (\%) } \\
\hline & & $\begin{array}{l}\text { Belediye } \\
\text { Başkanlığı }\end{array}$ & $\begin{array}{l}\text { Büyükşehir } \\
\text { Belediye } \\
\text { Başkanlığı }\end{array}$ & $\begin{array}{l}\text { İ Genel Meclis } \\
\text { Üyeliği }\end{array}$ & $\begin{array}{l}\text { Belediye Meclis } \\
\text { Üyeliği }\end{array}$ \\
\hline $\begin{array}{l}\text { Adalet ve } \\
\text { Kalkınma } \\
\text { Partisi (AKP) }\end{array}$ & 49,8 & 43,1 & 45,5 & 45,4 & 42,9 \\
\hline $\begin{array}{l}\text { Büyük Birlik } \\
\text { Partisi (BBP) }\end{array}$ & 0,8 & 1,4 & 0,7 & 2,3 & 1,5 \\
\hline $\begin{array}{l}\text { Cumhuriyet } \\
\text { Halk Partisi } \\
\text { (CHP) }\end{array}$ & 26,0 & 26,4 & 31,0 & 16,8 & 26,3 \\
\hline $\begin{array}{l}\text { Demokrat } \\
\text { Parti (DP) }\end{array}$ & 0,7 & 0,7 & 0,2 & 1,0 & 0,7 \\
\hline $\begin{array}{l}\text { Demokratik } \\
\text { Sol Parti (DSP) }\end{array}$ & 0,3 & 0,4 & 0,1 & 0,3 & 0,3 \\
\hline $\begin{array}{l}\text { Doğru Yol } \\
\text { Partisi (DYP) }\end{array}$ & 0,2 & $0,027376^{8}$ & $0,085144^{5}$ & $0,036435^{5}$ & $0,026528^{5}$ \\
\hline $\begin{array}{l}\text { Emek Partisi } \\
\text { (EMEP) }\end{array}$ & 0,1 & $0,001089^{5}$ & $0^{9}$ & $0^{6}$ & $0,00118^{5}$ \\
\hline $\begin{array}{l}\text { Hak ve Eşitlik } \\
\text { Partisi } \\
\text { (HEPAR) }\end{array}$ & 0,3 & $0,042151^{5}$ & $0,115851^{5}$ & $0,026543^{5}$ & $0,08208^{5}$ \\
\hline $\begin{array}{l}\text { Liberal } \\
\text { Demokrat } \\
\text { Parti (LDP) }\end{array}$ & $0,035448^{5}$ & $0,035236^{5}$ & $0,020828^{5}$ & $0,100137^{5}$ & $0,021941^{5}$ \\
\hline Millet Partisi & 0,1 & $0,04456^{5}$ & $0,057745^{5}$ & $0,039814^{5}$ & $0,036243^{5}$ \\
\hline $\begin{array}{l}\text { Milliyetçi } \\
\text { Hareket } \\
\text { Partisi (MHP) }\end{array}$ & 13,0 & 17,7 & 13,6 & 20,6 & 17,8 \\
\hline $\begin{array}{l}\text { Saadet Partisi } \\
\text { (SP) }\end{array}$ & 1,3 & 2,8 & 1,7 & 3,3 & 2,8 \\
\hline $\begin{array}{l}\text { Türkiye } \\
\text { Komünist } \\
\text { Parti (TKP) }\end{array}$ & 0,1 & $0,018862^{5}$ & $0,032609^{5}$ & $0,075576^{5}$ & $0,145203^{5}$ \\
\hline Bağımsızlar & 6,6 & 0,2 & 0,6 & 0,4 & 0,1 \\
\hline
\end{tabular}

Kaynak: www.tuik.gov.tr

\footnotetext{
${ }^{8}$ İlgili seçimde \%0,1'in altında oy oranına sahip olmuştur. Almış olduğu oy sayısı çok az olduğu için TÜíK verilerinde oy oranı 0 olarak gösterilmiştir. Analizlerin daha sağılılı olması için Geçerli Oy Sayısı / Alınan Oy Sayısı işlemi ile tekrar hesaplanmıştır.

9 İlgili seçime katılmamıştır.
} 
12 Haziran 2011 milletvekilliği genel seçimlerinde son iki milletvekilliği genel seçiminde olduğu gibi AKP \%49,8 oy oranı ile seçimi ilk sırada tamamlamıştır. 6 Mayıs 2014 mahalli idareler seçimlerinde sırasıly $\% 43,1$; $\% 45,5$; il genel meclis üyeliği seçimlerinde $\% 45,4$ ve belediye meclis üyeliği seçimlerinde \%42,9 oy oranları ile AKP birinci olmuştur.

\section{Metodoloji}

Literatürde, Türkiye'de genel seçimlerin yerel seçimler üzerindeki etkisini araştıran çalışmalara çok fazla rastlanmamıştır. Bu konuda yapılan çalışmalara bakıldığında Altan'ın yaptığı “Genel Seçimler-Yerel Seçimler İlişkisi (1983-2004)” isimli çalışmasında araştırmacı, iktidardaki partilerin ülke yönetiminin tamamında söz sahibi olma arzusu olduğunu ve bunu halka yakın olan birimlerde özellikle elde etmeye çalıştığını vurgulamakta bu sebeple yerel seçimlerin öneminin arttığını savunmaktadır. Bunun bir sonucu olarak yerel seçimler ile genel seçimlerin ilişkilendirildiğini belirten araştırmacı yaptığı değerlendirmelerde, Türkiye'de yerel seçimlerde iktidar partilerinin ellerindeki gücü kullanarak daha başarılı oldukları kanısının var olduğunu söylemiştir. Araştırma sonuçlarında ise, iktidar partisi olmanın her zaman yerel seçim sonuçlarına olumlu etkisi olmadığı, hatta bu durumun bazı zamanlarda olumsuz sonuçlar doğurduğu bir istisna olarak belirtilmiştir. Siyasal kurumsallaşmanın henüz sağlanamaması sebebi ile parti politikalarında değişimin fazla olduğu, yönetimde istikrarın sağlanamadığı, bu durumun yerel seçimlere de yansıdığı savunulmuştur (Altan, 2005, s. 188-189). Kamalak (2013) tarafından yapılan, yerel seçimlerin ulusal seçimlerin gölgesinde yapıldığı, iktidar partisi olmanın belediye başkanlığ seçimlerinde bir avantaj olarak kabul edildiği ve belediye seçimlerinde başkan adaylarının belli bir oranda etkisi olduğu varsayımlarını sorgulayan araştırmada ise ulusal seçim sonuçlarının yerel seçim sonuçları üzerinde bir etkisinin var olduğu ancak bu etkinin seçmen sayısı azaldıkça yani seçim bölgesi küçüldükçe azaldığ belirlenmiştir. Araştırmaya göre seçim bölgesi büyük olan yerel seçimlerde seçmen davranışı rasyonel tercih modeline uygunken, seçim bölgesi küçüldükçe seçmen davranışının sosyolojik modele göre şekillendiği görülmektedir.

\section{Çalışmanın Amacı}

Çalışmanın amacı, rasyonel tercih modeli bağlamında milletvekilliği genel seçimlerinde partilerin almış oldukları oy oranının ilgili milletvekilliği genel seçimi sonrasında yapılan mahalli idareler seçimlerinde alınan oy oranları üzerindeki etkisinin araştırılmasıdır. Bu amaç doğrultusunda 24 Haziran 2018 tarihinde yapılan milletvekilliği genel seçim sonuçlarına göre Türkiye Büyük Millet Meclisi (TBMM)'nde sandalye hakkı kazanan partilerin almış oldukları Türkiye geneli oy oranlarına göre 31 Mart 2019 tarihinde yapılacak olan mahalli idareler seçimlerinde alabilecekleri oy oranları tahmini gerçekleştirilmiştir.

\section{Veri Seti ve Kullanılan Analiz Yöntemi}

Çalışmada benimsenen amaç doğrultusunda Türkiye de 1980 sonrası yapılan 1983, 1987, 1991, 1995. 2002, 2007 ve 2011 milletvekilliği genel seçimlerinde alınan oy oranları ile 1984, 1989, 1994, 1999, 2004, 2009 ve 2014 mahalli idareler seçimlerinde alınan oy oranları ele alınmıştır. Herhangi bir milletvekilliği genel seçimine girmemiş bir partinin bir sonraki mahalli idareler seçimine girmiş olması ya da tam tersi bir durumun söz konusu olması analize dâhil 
edilmemiştir. 1983 milletvekilliği genel seçimlerine ve 1984 mahalli idareler seçimlerine ilişkin resmi rapor ve verilere ulaşılamadığı için ilgili seçimler de analiz dışında tutulmuştur. Analiz dışında tutulan bir diğer seçim ise 18 Nisan 1999 milletvekilliği genel seçimleri olmuştur. $\mathrm{Bu}$ seçimlerin analiz dışında tutulmasının nedeni, 18 Nisan 1999 milletvekilliği genel seçimlerinin ardından 3 Kasım 2002 de erken seçim yapılmış olmasıdır. Ayrıca milletvekilliği genel seçimlerinde ve mahalli idareler seçimlerinde seçime dahil olan bağımsız adaylar aynı kişiler olmadığı için bağımsız adaylar da analize dahil edilmemiştir. Analizler ilk olarak yapılan milletvekilliği genel seçimlerine katılmış partilerin oy oranları ile bir sonraki mahalli idareler seçimlerine katılan aynı partilerin almış oldukları oy oranları temel alınarak gerçekleştirilmiştir. Ayrıca mahalli idareler seçimleri; belediye başkanlığı seçimleri, büyükşehir belediye başkanlığ seçimleri, il genel meclis üyeliği seçimleri ve belediye meclis üyeliği seçimleri olarak dört alt grupta incelenmiş olup milletvekilliği genel seçimlerinde alınan oy oranlarının tüm alt gruplarda alınan oy oranları üzerindeki etkisi analiz edilmiştir. Çalışmanın amacına yönelik olarak kurulan hipotezler aşağıda verilmiştir.

$\mathbf{H}_{1}$ : Milletvekilliği genel seçimlerinde alınan oy oranlarının belediye başkanlığı seçimlerinde alınan oy oranları üzerinde etkisi yoktur.

$\mathbf{H}_{2}$ : Milletvekilliği genel seçimlerinde alınan oy oranlarının büyükşehir belediye başkanlığ seçimlerinde alınan oy oranları üzerinde etkisi yoktur.

$\mathbf{H}_{3}$ : Milletvekilliği genel seçimlerinde alınan oy oranlarının il genel meclis üyeliği seçimlerinde alınan oy oranları üzerinde etkisi yoktur.

$\mathbf{H}_{4}$ : Milletvekilliği genel seçimlerinde alınan oy oranlarının belediye meclis üyeliği seçimlerinde alınan oy oranları üzerinde etkisi yoktur.

Milletvekilliği genel seçimlerinde alınan oy oranlarının mahalli idareler seçimlerinde alınan oy oranları üzerindeki etkisinin ölçülmesi için basit regresyon analizi tekniği kullanılmıştır. Basit doğrusal regresyon analizi, aralarında teorik bir ilişki olduğu düşünülen iki değişkenden bağımlı değişkenin bağımsız değişken üzerindeki etkisini ölçmeye yarayan parametrik bir analiz yöntemidir. Tüm parametrik analiz yöntemlerinin temel varsayımı olan normal dağılıma uygunluk ya da kısaca normallik varsayımı basit doğrusal regresyon analizi yöntemi için de geçerli olmaktadır. Normallik varsayımının sağlanmaması, analiz sonucunda elde edilen bulguların olduğundan farklı ortaya çıkmasına sebep olmaktadır. Bu nedenle normallik varsayımının sağlanması oldukça önemli bir ölçüm olarak karşımıza çıkmaktadır.

Normalliği değerlendirmenin gerek grafiksel gerekse bazı istatistiksel parametreleri hesaplama gibi farklı yolları bulunmaktadır. Grafiksel yöntemlerden en basit ve en yaygın kullanılan yöntemlerinden birisi veri dağılımının histogramını oluşturmak ve normal eğri çizdirerek grafiği incelemektir. İstatistiksel parametreleri hesaplama yöntemlerinde ise özellikle basıklık ve çarpıklık katsayılarının incelenmesi oldukça sık kullanılmaktadır. Standart normal dağılım, sıfır basıklık ve sıfır çarpıklık katsayılarına sahip olmaktadır. Basıklık ve çarpıklık katsayısı değerlerinin \pm 1 değerleri arasında kalması, dağılımın normalden aşırı sapma göstermediğinin yani dağılımın normal dağılıma oldukça yakın olduğunun bir kanıtı olarak kabul edilmektedir (Çokluk vd., 2012, s. 16). 
Veriler normal dağılıma uygunluk göstermemesi halinde değişkenler üzerinde dönüşümler uygulanarak verilerin normal dağılıma yaklaşması sağlanabilmektedir. Verinin çarpıklık katsayısına göre uygulanacak dönüşüm yöntemleri aşağıda özetlenmiştir.

\section{Tablo 9. Normal Dağılım Elde Etmek İçin Yaygın Olarak Kullanılan Dönüştürme Yöntemleri}

\begin{tabular}{|l|l|}
\hline Çarpıklık Derecesi & Dönüşüm Türü \\
\hline Orta düzeyde pozitif çarpık & Karekök alma $(\sqrt{\mathrm{X}})$ \\
\hline Yüksek düzeyde pozitif çarpıklık & Logaritma alma $\left(\log _{10}(\mathrm{X})\right)$ \\
\hline Aşırı düzeyde pozitif çarpıklık & Ters çevirme $(1 / \mathrm{X})$ \\
\hline Orta düzeyde negatif çarpıklık & Yansıtma \& Karekök alma $\left(\sqrt{\left.(\mathrm{b}-\mathrm{X})^{\mathrm{b}}\right)}\right.$ \\
\hline Yüksek düzeyde negatif çarpıklık & Yansıtma \& Logaritma alma $\left(\log _{10}(\mathrm{~b}-\mathrm{X})^{\mathrm{b}}\right)$ \\
\hline Aşırı düzeyde negatif çarpıklık & Yansıtma \& Ters çevirme $1 /(\mathrm{b}-\mathrm{X})^{\mathrm{b}}$ \\
\hline
\end{tabular}

b: En küçük değerin 1'e eşit olması için her değerden çıkarılan sabit

Kaynak: Çokluk vd., 2012: 17

Bazı değişkenlerin arasındaki ilişkinin test edilmesinde, değişkenler arasındaki ilişki yukarıdaki gibi basit doğrusal regresyon analizine uymayabilir. Verilerin normal dağılıma uymaması halinde logaritmik dönüşümler yapılarak hem normallik varsayımı sağlanabilir hem de değişkenler arasındaki ilişki doğrusal olmayan kalıplara dönüştürülerek analizler gerçekleştirilebilir. Bu kapsamda en sık kullanılan basit doğrusal olmayan regresyon analizi denklemleri aşağıdaki gibidir (Yıldırtan, 2011, s. 93).

$$
\begin{array}{ll}
\ln Y=\beta_{0}+\beta_{1}(X)+\varepsilon & \text { logaritmik doğrusal } \\
\ln Y=\ln \beta_{0}+\beta_{1}(\ln X)+\varepsilon & \text { logaritmik logaritmik } \\
Y=\ln \beta_{0}+\beta_{1}(\ln X)+\varepsilon & \text { doğrusal logaritmik }
\end{array}
$$

Basit regresyon analizi uygulamadan önce verilerin normal dağılıma uygunluğu incelendikten sonra basit regresyon analizi uygulanabilir. Basit regresyon analizi genel olarak basit doğrusal regresyon analizi ve basit doğrusal olmayan regresyon analizi olarak iki grupta incelenmektedir. Anakütle için basit doğrusal regresyon analizi eşitliği aşağıdaki gibidir.

$$
\mathrm{Y}=\beta_{0}+\beta_{1}(\mathrm{X})+\varepsilon
$$

Yukarıdaki eşitlikte $Y$ bağımlı ve $X$ bağımsız değişkenler olmak üzere, $\beta_{0}$; modeldeki sabit katsayıyı, $\beta_{1}$; X değişkeninin katsayısını ve $\varepsilon$ ise hata terimini ifade etmektedir.

Anakütle için basit doğrusal regresyon analizi eşitliğine karşılık olarak örneklemden elde edilen aşağıdaki eşitlik için katsayı değerleri bulunur.

$$
\hat{y}=a+b x
$$

Yukarıdaki eşitlikte $a$ ve $b$ katsayılarının bulunması için en sık kullanılan yöntem en küçük kareler (EKK) yöntemidir. EKK yönteminde, bağımlı değişkenin her bir gözlenen değeri $\left(y_{i}\right)$ ile her bir hesaplanan değeri $\left(\hat{y}_{i}\right)$ arasındaki farkların $\left(e_{i}\right)$ toplamı sıfır, kareleri toplamı minimum olacak şekilde doğrunun katsayıları değerlendirilir. Matematiksel olarak $a$ ve $b$ katsayıları aşağıdaki eşitlikler ile ifade edilebilir (Armutlulu, 2008, s. 154). 


$$
\begin{gathered}
b=\frac{\mathrm{n}\left(\sum_{\mathrm{i}=1}^{\mathrm{n}} \mathrm{x}_{\mathrm{i}} \mathrm{y}_{\mathrm{i}}\right)-\left(\sum_{\mathrm{i}=1}^{\mathrm{n}} \mathrm{x}_{\mathrm{i}}\right)\left(\sum_{\mathrm{i}=1}^{\mathrm{n}} \mathrm{y}_{\mathrm{i}}\right)}{\mathrm{n}\left(\sum_{\mathrm{i}=1}^{\mathrm{n}} \mathrm{x}_{\mathrm{i}}^{2}\right)-\left(\sum_{\mathrm{i}=1}^{\mathrm{n}} \mathrm{x}_{\mathrm{i}}\right)^{2}} \\
a=\frac{\sum_{\mathrm{i}=1}^{\mathrm{n}} \mathrm{y}_{\mathrm{i}}-b \sum_{\mathrm{i}=1}^{\mathrm{n}} \mathrm{x}_{\mathrm{i}}}{\mathrm{n}}
\end{gathered}
$$

Bu denklemler ile bulunan $a$ ve $b$ katsayıları anakütle regresyon doğrusundaki $\beta_{0}$ ve $\beta_{1}$ parametrelerinin kestirim değerleridir.

Regresyon analizi çalışmaları için gerekli olan diğer bir aşama, örnekleme göre geliştirilen modelin güvenilirliğinin ölçülmesidir. Örnekleme göre geliştirilen model sonuçları gözlem değerlerine ne kadar yakınsa tahmin güvenilirliği o kadar yüksektir. İstatistikçiler tahmin eşitliğinin güvenilirliğinin ölçülmesi için tahminin standart hatası kavramını geliştirmişlerdir. Standart hata $\mathrm{s}_{\mathrm{yx}}$ olmak üzere matematiksel ifade aşağıdaki gibidir (Tütek ve Gümüşoğlu, 2011, s. 197):

$$
\mathrm{s}_{\mathrm{yx}}=\sqrt{\frac{\sum_{\mathrm{i}=1}^{\mathrm{n}}\left(\mathrm{y}_{\mathrm{i}}-\hat{\mathrm{y}}_{\mathrm{i}}\right)^{2}}{\mathrm{n}-2}}
$$

Bağımlı değişkendeki değişmelerin yüzde kaçının modelde bağımsız değişken tarafından açıklanabildiğinin belirlenmesi de belirginlik katsayısının hesaplanmasıyla elde edilmektedir. Belirginlik katsayısı 0 ile 1 arasında bir değer alır. Belirleme katsayısının 1'e yakınlaşması modeldeki bağımsız değişkenin bağımlı değişkendeki varyansın büyük bir kısmını açıkladığını göstermektedir (Esin vd., 2006, s. 541). Belirginlik katsayısı aşağıdaki eşitlik ile elde edilmektedir.

$$
\mathrm{R}^{2}=\frac{\sum_{\mathrm{i}=1}^{\mathrm{n}}\left(\hat{\mathrm{y}}_{\mathrm{i}}-\overline{\mathrm{y}}\right)^{2}}{\sum_{\mathrm{i}=1}^{\mathrm{n}}\left(\mathrm{y}_{\mathrm{i}}-\overline{\mathrm{y}}\right)^{2}}
$$

Eşitlikte yer alan $R^{2}$, belirginlik katsayısını ve $\overline{\mathrm{y}}$ ise gözlem değerlerinin ortalamasını ifade etmektedir.

Basit regresyon analizinde son olarak elde edilen sonuçların değerlendirilmesinde iki önemli sınama bulunmaktadır. Bunlardan birincisi doğrusal modelde katsayı konumundaki $\beta_{0}$ ve $\beta_{1}$ parametreleri sınamasıdır. Bu sınamalar t sınaması ile yapılır ve amaç örneklem için oluşturulan modeldeki $a$ ve $b$ katsayılarının anlamlılığının test edilmesidir. İkinci tür sınama ise $\mathrm{F}$ sınamasıdır. F sınaması ise genel olarak modelin geçerliliğinin/anlamlılığının test edilmesidir (Armutlulu, 2008, s. 164). 


\section{Bulgular}

Milletvekilliği genel seçimlerinde alınan oy oranlarının mahalli idareler seçimlerinde alınan oy oranları üzerindeki etkisini araştırmak için başvurulan basit regresyon analizinin uygulanması için ele alınan verilerin normal dağılıma sahip olması gerekmektedir. Bu nedenle öncelikle verilerin normal dağılıma uygun olup olmadığı çarpıklık ve basıklık katsayılarının hesaplanması ile belirlenmiştir. Yapılan hesaplamalar sonucu elde edilen çarpıklık ve basıklık katsayıları aşağıda özetlenmiştir.

Tablo 10. Çarpıklık ve Basıklık Katsayıları

\begin{tabular}{|c|c|c|c|c|}
\hline \multirow[b]{2}{*}{ Değişken } & \multicolumn{2}{|c|}{ Doğrudan Hesaplama } & \multicolumn{2}{|c|}{$\begin{array}{l}\text { Logaritmik }\left(\log _{10}\right) \text { Dönüşümlü } \\
\text { Hesaplama }\end{array}$} \\
\hline & Çarpıklık & Basıklık & Çarpıklık & Basıklık \\
\hline $\begin{array}{l}\text { Milletvekilliği genel seçimlerinde } \\
\text { alınan oy oranı (MVSO) }\end{array}$ & 1,752 & 2,910 & $-0,115$ & $1,371^{-}$ \\
\hline $\begin{array}{l}\text { Belediye başkanlığı seçimlerinde } \\
\text { alınan oy oranı (BBSO) }\end{array}$ & 1,512 & 1,615 & $-0,541$ & $0,614^{-}$ \\
\hline $\begin{array}{l}\text { Büyükşehir belediye başkanlığı } \\
\text { seçimlerinde alınan oy oranı (BBBSO) }\end{array}$ & 1,645 & 1,973 & $-0,153$ & $0,903^{-}$ \\
\hline $\begin{array}{l}\text { II genel meclis üyeliği seçimlerinde } \\
\text { alınan oy oranı (iGMSO) }\end{array}$ & 1,585 & 2,207 & $-0,372$ & $1,005^{-}$ \\
\hline $\begin{array}{c}\text { Belediye meclis üyeliği } \\
\text { seçimlerinde alınan oy oranı (BMSO) }\end{array}$ & 1,488 & 1,522 & $-0,377$ & 0,979 \\
\hline
\end{tabular}

İlk olarak verilerde herhangi bir işlem uygulamadan çarpıklık ve basıklık katsayıları hesaplanmış ve yukarıdaki tablonun sol kısmında yer alan doğrudan hesaplama kısmındaki değerler elde edilmiştir. Elde edilen çarpıklık ve basıklık katsayılarının \pm 1 aralığında olmamasından dolayı verilerin normal dağılıma uygun hale getirilmesi için 10 tabanında logaritmalar alınmış ve katsayılar tekrar hesaplanmıştır. Yapılan dönüşüm sonucunda çarpıklık ve basıklık katsayıları -1 ile +1 arasında yer aldıkları için dağılımın normal dağılıma oldukça yakınlaştığı sonucuna ulaşılmıştır.

Normal dağılım varsayımını yerine getirdikten sonra regresyon analizi uygulanmış ve sonuçlar Tablo 11'de özetlenmiştir. 
Tablo 11. Regresyon Analizi Sonuçları

\begin{tabular}{|c|c|c|c|c|c|c|c|c|}
\hline \multirow[b]{2}{*}{ Model } & & & \multirow[b]{2}{*}{ t Değeri } & \multirow{2}{*}{$\begin{array}{c}\text { \%95 İç } \\
\text { Tutarlılık } \\
\text { Düzeyi }\end{array}$} & \multirow{2}{*}{$\begin{array}{c}\text { Standart } \\
\text { Hata }\end{array}$} & \multicolumn{2}{|c|}{$\begin{array}{c}\text { Model } \\
\text { Anlamlılığı }\end{array}$} & \multirow[b]{2}{*}{$\mathbf{R}^{2}$} \\
\hline & \multicolumn{2}{|c|}{ Katsayılar } & & & & $\mathbf{F}$ & $\begin{array}{c}\text { \%95 İç } \\
\text { Tutarlılık } \\
\text { Düzeyi }\end{array}$ & \\
\hline \multirow{2}{*}{ MVSO*BBSO } & $\alpha$ & $-0,335$ & $-4,627$ & ,000 & 0,072 & \multirow{2}{*}{237,091} & \multirow{2}{*}{,000 } & \multirow{2}{*}{0,782} \\
\hline & $\beta$ & 1,205 & 15,398 & ,000 & 0,078 & & & \\
\hline \multirow{2}{*}{ MVSO*BBBSO } & $\alpha$ & $-0,438$ & $-5,828$ & ,000 & 0,075 & \multirow{2}{*}{223,697} & \multirow{2}{*}{,000 } & \multirow{2}{*}{0,772} \\
\hline & $\beta$ & 1,209 & 14,957 & ,000 & 0,081 & & & \\
\hline \multirow{2}{*}{ MVSO*iGMSO } & $\alpha$ & $-0,186$ & $-3,048$ & ,003 & 0,061 & \multirow{2}{*}{263,543} & \multirow{2}{*}{,000 } & \multirow{2}{*}{0,805} \\
\hline & $\beta$ & 1,069 & 16,234 & ,000 & 0,066 & & & \\
\hline \multirow{2}{*}{ MVSO*BMSO } & $\alpha$ & $-0,421$ & $-5,905$ & ,000 & 0,071 & \multirow{2}{*}{267,012} & \multirow{2}{*}{,000 } & \multirow{2}{*}{0,802} \\
\hline & $\beta$ & 1,257 & 16,341 & ,000 & 0,077 & & & \\
\hline
\end{tabular}

Tablo 11'de yer alan $\mathrm{R}^{2}$ değeri milletvekilliği genel seçiminde alınan oy oranının, mahalli idareler seçimlerinde alınan oy oranları üzerindeki değişimi açıllama gücünü göstermektedir. Buna göre belediye başkanlığı seçimlerinde alınan oy oranındaki değişimin \%78,2'si ve büyükşehir belediye başkanlığı seçimlerinde alınan oy oranındaki değişimin \%77,2'si milletvekilliği genel seçimlerinde alınan oy oranı ile açıklanmaktadır. İl genel meclis üyeliği seçimlerinde alınan oy oranındaki değişimin $\% 80,5$ 'i ve belediye meclis üyeliği seçimlerinde alınan oy oranındaki değişimin \%80,2'si de milletvekilliği genel seçimlerinde alınan oy oranı ile açıklanmaktadır. Genel olarak milletvekilliği genel seçimlerinde alınan oy oranlarının mahalli idareler seçimlerinde alınan oy oranları üzerinde \%75'in üzerinde bir etkisinin olduğunu söylemek mümkündür. Kurulan modelin anlamlı olup olmadığına ilişkin test sonuçları incelendiğinde F değerinin oldukça yüksek olması ve bu değere ait \%95 iç tutarlılık düzeylerinin 0,05'den küçük olması modelin anlamlı olduğunu ifade etmektedir. Bu sonuçla milletvekilliği genel seçimlerinde alınan oy oranlarının mahalli idareler seçimlerinde alınan oy oranları üzerindeki etkisine ilişkin kurulan hipotezlerin tamamının kabul edilemeyeceği yani milletvekilliği genel seçimlerinin mahalli idareler seçimleri üzerinde anlamlı bir etkisinin olduğu sonucuna ulaşılmıştır. Bununla beraber katsayılara ait \%95 iç tutarlılık düzeylerinin de 0,05'den küçük olması bulunan katsayı değerlerinin de anlamlı olduğunu göstermektedir. Katsayılara ait standart hata değerleri de incelendiğinde çok yüksek standart hata değerlerinin olmaması, katsayıların anlamlı olduğunu destekleyen bir diğer ölçü olarak kabul edilebilir. Analiz sonucunda hesaplanan a ve b katsayılarına göre ortaya çıkan modeller aşağıdaki gibi olmuştur.

\footnotetext{
$\log _{10}($ BBSO $)=-0,335+1,205^{\star} \log _{10}($ MVSO $)$

$\log _{10}($ BBBSO $)=-0,438+1,209^{*} \log _{10}(\mathrm{MVSO})$

$\log _{10}(\mathbf{I} G M S O)=-0,186+1,069^{*} \log _{10}($ MVSO $)$

$\log _{10}(\mathbf{B M S O})=-0,421+1,257^{\star} \log _{10}(\mathrm{MVSO})$
} 
Yukarıdaki modelde yer alan logaritmaların ortadan kaldırılarak daha anlaşılır bir hale getirilmesi için öncelikle sabit katsayıların antilogaritması alınır ve basitleştirilmiş modeller aşağıdaki gibi elde edilir.

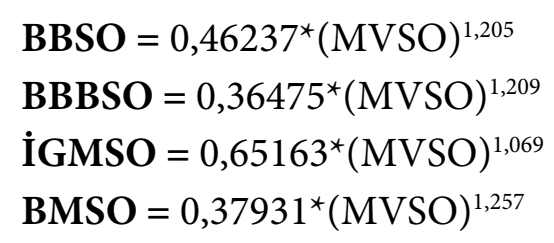

Buna göre milletvekilliği genel seçimlerinde alınan oy oranındaki \%1'lik artış takip eden belediye başkanlığı seçimlerinde alınacak oy oranı üzerinde \%1,205'lik bir artış sağlamaktadır. Milletvekilliği genel seçimlerinde alınan oy oranının büyükşehir belediye başkanlığ seçimlerinde alınacak oy oranı üzerindeki etkisi ise \%1,209'luk bir artı̧s şeklinde olurken, milletvekilliği genel seçimlerinde alınan oy oranındaki \%1'lik artıs takip eden il genel meclis üyeliği seçimlerinde alınacak oy oranının üzerinde \%1,069'luk bir artı̧s sağlamaktadır. Son olarak milletvekilliği genel seçimlerinde alınan oy oranındaki \%1 artı̧ bir sonraki belediye meclis üyeliği seçimlerinde alınacak oy oranını \%1,257 arttırabilecektir.

\section{Sonuç}

Türkiye'de seçmenlerin yöneticilerini seçme üzerine genel kanaati incelendiğinde parlamentoda çoğunluğa sahip siyasi partilere mensup yerel yöneticilerin seçilmesiyle birlikte kamu hizmetlerinin merkezden yerele doğru daha hızlı, daha verimli ve daha etkin sunulacağ 1 anlayışının hâkim olduğu söylenebilir. Söz konusu kanaatten hareketle yapılan bu çalışmada milletvekilliği genel seçimlerinde alınan oy oranlarının büyük ölçüde mahalli idareler seçimlerinde alınan oy oranları üzerinde pozitif bir etkiye sahip olduğu sonucuna ulaşılmıştır. Elde edilen bulgular incelendiğinde milletvekilliği genel seçimlerinde alınan oy oranlarının belediye başkanlığı seçiminde alınan oy oranları üzerinde \%78,2; büyükşehir belediye başkanlığı seçiminde alınan oy oranları üzerinde $\% 77,2$; il genel meclisi üyeliği seçiminde alınan oy oranları üzerinde $\% 80,5$ ve belediye meclis üyeliği seçiminde alınan oy oranları üzerinde $\% 80,2$ oranında etki ettiği görülmüştür. Dolayısıyla genel olarak ele alındığında milletvekilliği genel seçimlerinde alınan oy oranlarının, mahalli idareler seçimlerinde alınan oy oranları üzerinde \%77'nin üzerinde artı yönde etkisinin olduğu tespit edilmiştir. 1980 sonrasında yapılan milletvekilliği genel seçimlerinde partilerin almış oldukları oy oranları ile aynı partilerin mahalli idareler seçimlerinde aldıkları oy oranları incelendiğinde tespit edilen sonuç desteklenmektedir. Bu durumun dışında gerçekleşen istisnai durumlar mevcuttur. Bunlardan birincisi 29 Kasım 1987 milletvekilliği genel seçimlerinde ANAP en çok oy oranına sahip olurken 26 Mart 1989 mahalli idareler seçimlerinde en çok oy oranına sahip parti SHP olmuştur. Bunun nedeni olarak ANAP'ın iktidar politikalarının seçmenler tarafından benimsenmeyip SHP'nin söylemlerinin seçmenleri etkilediği düşünülmektedir. İkinci istisnai durum ise 24 Aralık 1995 milletvekilliği genel seçimlerinde RP en çok oy oranına sahip olmuştur. Ancak bir sonraki mahalli idareler seçimlerine katılamadığından analize dâhil edilmemiştir. Dolayısıyla analize dâhil edilen partiler içerisinde en çok oy oranına sahip parti 
ANAP olmuştur. 18 Nisan 1999 mahalli idareler seçimlerinde ise en çok oy oranına sahip parti DSP'dir. Bunun nedeni olarak da 24 Aralık 1995 milletvekilliği genel seçimlerinde hiçbir parti tek başına iktidar olamamış ve koalisyon denemeleri yapılmıştır. Ancak siyasi istikrarsızlıktan dolayı 1999 yılında aynı anda yapılan hem milletvekilliği genel gen seçimleri hem de mahalli idareler seçimlerinde seçmenler aynı siyasi partiyi desteklemişlerdir.

Çalışmanın amacına yönelik olarak 24 Haziran 2018 tarihinde yapılan milletvekilliği genel seçim sonuçlarına göre 31 Mart 2019 tarihinde yapılacak olan mahalli idareler (Belediye Başkanlığı, Büyükşehir Belediye Başkanlığı, İl Genel Meclis Üyeliği ve Belediye Meclis Üyeliği) seçimlerinde partilerin alacağı oy oranlarının tahminleri yapılmıştır. Hesaplanan oy oranları tahminleri, eski seçim sonuçlarına göre doğrulama yapıldığında $\pm \% 6$ puanlık bir sapma ile gerçekleştirilmiştir. Bu sebeple 31 Mart 2019 tarihinde yapılacak olan mahalli idareler seçimlerinde partilerin alacağı oy oranları tahminlerinde de $\pm \% 6$ puanlık bir sapmanın yaşanabileceğini ifade etmek gerekir. TÜİK tarafından açıklanan 24 Haziran 2018 tarihinde yapılan milletvekilliği genel seçim sonuçlarına göre AKP \%42,6; CHP \%22,6; MHP \%11,1; HDP \%11,7 ve İyi Parti (IYP) ise \%10,0 oy oranına ulaşmıştır. Milletvekilliği genel seçimlerinde alınan oy oranları baz alınarak mahalli idareler seçimlerinde alınan oy oranlarının tahminine ilişkin elde edilen model yardımıyla 2019 yılı mahalli idareler seçimlerinde tahmin edilen oy oranları şu şekildedir:

- Belediye Başkanlığı seçimlerinde AKP’nin \%42,5; CHP’nin \%19,8; MHP’nin \%8,41; HDP'nin \%8,96 ve İYP'nin ise \%7,41 oy oranına ulaşacağ 1 tahmin edilmektedir.

- Büyükşehir Belediye Başkanlığı seçimlerinde AKP’nin \%34,04; CHP’nin \%15,82; MHP'nin \%6,7; HDP'nin \%7,14 ve İY'nin ise \%5,9 oy oranına ulaşacağı tahmin edilmektedir.

- İl Genel Meclis Üyeliği seçimlerinde AKP'nin \%35,96; CHP’nin \%18,26; MHP’nin \%8,54; HDP’nin \%9,03 ve İYP'nin ise \%7,64 oy oranına ulaşacağ tahmin edilmektedir.

- Belediye Meclis Üyeliği seçimlerinde AKP’nin \%42,38; CHP’nin \%19,1; MHP’nin $\% 7,82$; HDP'nin \%8,35 ve İYP'nin ise $\% 6,85$ oy oranına ulaşacağ 1 tahmin edilmektedir.

Yapılan çalışmada her iki seçim için sadece oy oranları dikkate alınmıştır. Seçim beyannameleri, adayların özellikleri ve seçim kampanyaları gibi seçimi etkileyebilecek değişkenlerin değerlendirmeye katılarak çalışmanın genişletilmesi mümkündür. Analiz kapsamında milletvekilliği genel seçimlerindeki mevcut koşullar mahalli idareler seçimleri için de kabul edildiğinden farklı değişkenler kullanılarak bu koşullar da analize dâhil edilebilir. Bunların yanı sıra, seçmen davranışlarını etkileyen diğer modeller de göz önüne alınarak çalışma kapsamı genişletilebilir. 


\section{Kaynakça}

Akgün, B. (2007). Türkiye'de Seçmen Davranışı, Partiler Sistemi ve Siyasal Güven. Ankara: Nobel Yayın Dağıtım.

Altan, C. (2005). Genel Seçimler-Yerel Seçimler İlişkisi (1983-2004). Elektronik Sosyal Bilimler Dergisi, 4(12), 174-190. url: http://dergipark.gov.tr/esosder/issue/6126/82175

Armutlulu, İ. H. (2008). İsletmelerde Uygulamalı İstatistik. İstanbul: Alfa.

Barut, B. (2005). Siyasal Reklamcılık Özelinde Siyasal Tutumların Oluşması Süreci. Fırat Üniversitesi Sosyal Bilimler Dergisi, 15(2), 295-317. url: http://web.firat.edu.tr/sosyalbil/dergi/arsiv/cilt15/sayi2/295-317.pdf.

Berelson, B. R., Lazarsfeld, P. F. M. ve Willian, N. (1954). Voting: A Study of Opinion Formation in A Presidential Campaign. Chicago: University of Chicago Press.

Bilir, F. (2001). Türkiye'de Milletvekilliği ve Milletvekilliğin Sona Ermesi. Ankara: Nobel Yayın Dağıtım.

Çinko, L. (2006). Seçmen Davranışları ile Ekonomik Performans Arasındaki İlişskilerin Teorik Temelleri ve Türkiye Üzerine Genel Bir Değerlendirme. Ankara Üniversitesi Siyasal Bilgiler Fakültesi Dergisi, 61(1), 103-116. url: http://dergipark.gov.tr/ausbf/issue/3087/42752.

Çokluk Ö., Şekercioğlu G. ve Büyüköztürk Ş. (2012). Sosyal Bilimler İçin Çok Değişkenli İstatistik SPSS ve LISREL Uygulamaları. Ankara: Pegem Akademi.

Downs, A. (1957). An Economic Theory of Democracy. New York: Harper Collins Publishers.

Erdoğan, S. (2004). Politik Konjonktür Hareketleri Teorisi Perspektifi ile Siyaset-Ekonomi İlişkileri. İstanbul: Değişim Yayınevi.

Esin, A. A., Ekni, M. ve Gamgam, H. (2006). İstatistik. Ankara: Gazi Kitabevi.

Gülmen, Y. (1979). Türk Seçmen Davranışı: 1960-1970. İstanbul: İstanbul Üniversitesi İktisat Fakültesi.

Heywood, A. (2007). Siyaset. Buğra Kalkan (Çev.). Ankara: Liberte Yayınları.

Kalender, A. (2005). Siyasal İletişim: Seçmenler ve İkna Stratejileri. Konya: Çizgi Kitabevi.

Kamalak, İ. (2013). Yerelin Yerel Seçimlere Etkisi: Belediye Başkan Adayları Üzerinden Bir İnceleme. Dokuz Eylül Üniversitesi Sosyal Bilimler Enstitüsü Dergisi, 15(3), 419-446. url: http://dergipark.gov.tr/deusosbil/issue/4632/63145.

Kapani, M. (1988). Politika Bilimine Giriş. Ankara: Bilgi Yayınevi.

Ladd, J. M. (2006). Attitudes Toward the News Media and American Voting Behavior, In annual meeting of the Midwest Political Science Association.

Lakeman, E. ve Lambert, J. (1962). Voting in Democracies. London: Faber and Faber. 
Özcan, Y. Z. (1998). Siyasi Parti Tercihlerini Belirleyen Etmenler: İstanbul Örneği. Toplum ve Bilim Dergisi, 76, 188-212. url: dergisosyalbil.selcuk.edu.tr/susbed/article/download/619/851.

Özer, İ. ve Meder, M. (2008). Siyasal Katılma ve Seçmen Davranışı. İstanbul: Ege Yayınları.

Özkan, A. (2004). Siyasal İletişim. İstanbul: Nesil Matbaacılık.

Pomper, M. G. (1992). Concepts of Political Parties. Journal of Theoretical Politics, 4(2), 143159. doi: 10.1177/0951692892004002002.

TÜİK (Türkiye İstatistik Kurumu). https://biruni.tuik.gov.tr/secimdagitimapp/secim.zul, E.T: 12.01.2018.

TÜİK (Türkiye İstatistik Kurumu). https://biruni.tuik.gov.tr/secimdagitimapp/yerel.zul, E.T: 12.01.2018

Tütek, H. ve Gümüşoğlu, Ş. (2011). İşletme İstatistiği. İstanbul: Beta Basım.

Ünal B. A. (2016). Oy Verme Davranışı Modelleri. Ondokuz Mayı Üniversitesi Sosyal Bilimler Araştırmaları Dergisi, Temmuz, url: http://dergipark.gov.tr/odusobiad/issue/27575/290198.

Yıldırtan, D. Ç. (2011). E-Views Uygulamalı Temel Ekonometri Makro Ekonomik Verilerle. İstanbul: Türkmen Kitabevi. 